\title{
Measuring Civil Society: Perspectives on Afro-Centrism
}

\author{
Alan Fowler
}

Published online: 6 January 2012

(C) The Author(s) 2012. This article is published with open access at Springerlink.com

\begin{abstract}
International comparative research on civil society has subordinated Africa's diversity and specificities to other geographies and histories. Results are prejudiced global conceptualisations, questionable enumeration, problematic theory formulation and ill-conceived approaches to development initiatives intended to make African civil society 'stronger' and states more democratic. This article sets out a case for an endogenous approach to civil society enquiry as a political category sensitive to the continent's particularisms. In order to locate discussion about meanings, measures and measuring, a conceptual framework for research is described which avoids conflation with other epistemologies. Such a contribution will assist in sharpening thinking and discussion about the boundary characteristics of what is to be investigated.
\end{abstract}

Résumé La recherche comparative internationale sur la société civile a subordonné la diversité et les spécificités de l'Afrique à d'autres géographies et histoires. Les résultats sont des conceptualisations globales compromises, énumération incertaine, formulation problématique de théorie et des approches mal conçues aux initiatives de développement prévues pour rendre le stronger africain et les états de 'de société civile plus démocratiques. Cet article a visé un point de droit pour une approche endogène à l'enquête de société civile comme catégorie politique sensible aux particularisms du continent. Afin de localiser la discussion au sujet des significations, on décrit des mesures et la mesure, un cadre conceptuel pour la recherche qui évite le conflation avec d'autres épistémologies. Une telle contribution aidera derrière penser et à discussion d'affilage aux caractéristiques de frontière de ce qui doit être étudié.

\footnotetext{
A. Fowler $(\bowtie)$

International Institute for Social Studies, Erasmus University, Rotterdam, The Netherlands e-mail: alanfowler@compuserve.com
} 
Zusammenfassung Eine internationale vergleichbare Forschung auf dem Gebiet einer Zivilgesellschaft hat Afrikas Verschiedenartigkeit und Besonderheiten anderen Geographie und Geschichten unterstellt. Resultate sind befangene globale Konzeptualisierungen, fragliche Aufzählung, problematische Theorieformulierung und schlecht geplante Ansätze zu den Entwicklungsinitiativen, die afrikanisches die Zivilgesellschaft 'stronger und Zustände demokratischer bilden sollen. Dieser Artikel legte ein Argument für eine endogene Annäherung zur Zivilgesellschaftanfrage als politische Kategorie dar, die für die Particularisms des Kontinentes empfindlich ist. Um Diskussion über Bedeutungen zu lokalisieren, wird Masse und das Messen, ein Begriffsrahmen für Forschung beschrieben die conflation mit anderen epistemologies vermeidet. Solch ein Beitrag unterstützt im Schärfendenken und -diskussion über die Grenzeigenschaften von, was nachgeforscht werden soll.

Resumen La investigación comparativa internacional sobre sociedad civil ha subordinado la diversidad y las especificidades de África a otras geografías e historias. Los resultados son conceptualizaciones globales perjudicadas, enumeración cuestionable, formulación problemática de la teoría y acercamientos mal concebidos a las iniciativas del desarrollo previstas para hacer el stronger africano y los estados del 'de la sociedad civil más democráticos. Este artículo precisó un caso para un acercamiento endógeno a la investigación de la sociedad civil como categoría política sensible a los particularisms del continente. Para localizar la discusión sobre significados, las medidas y la medición, un marco conceptual para la investigación se describe que evita el conflation con otros epistemologies. Tal contribución asistirá al pensamiento y a la discusión de la afiladura sobre las características del límite de cuál debe ser investigado.

Keywords Civil society $\cdot$ Civic agency $\cdot$ Endogenous research ·

Measurement

\section{Introduction}

Research on civil society in Africa has been subjected to numerous foreign-derived concepts, often allied to externally driven knowledge agendas. This condition reflects a predisposition towards global knowledge systems premised on a Western epistemology. As in many other fields of study, Africa remains a battleground where contending western theories, institutional interests, neo-colonial perspectives, divergent schools and contrary positions are explored and played out. Critiques of such exogenous processes in terms of civil society philosophy, impositions on endogenous analysis and steering of local scholarship have come from both within and outside of the continent (e.g. Bayart 1986; Chambers and Kymlicka 2002; Kumar 1993; Mamdani 1996; Fowler 1998; Hearn 2001; Lewis 2002; Osaghae 2006). But these commentaries have yet to lead to a compelling and coherent examination of civil society from within, so to speak. This article builds on an existing initiative to remedy this situation. It has been inspired by a panel on Measuring Civil Society in Africa held 
at the 9th Biennial conference of the International Society for Third Sector Research in Istanbul in July 2010. The motivational statement for this panel argues that:

The continent, its researchers and its activists, have gained too little voice and substantive influence over how this analytic terrain has been understood, enumerated and explained. One result is incorporation of African phenomena into global development schemata that often mis-conceive indigenous realities to suit international comparisons and agendas. This panel offers an opportunity to re-consider how civil society in Africa can be conceived in its own terms and what, if at all, can be measured to better comprehend its influence on and beyond democracy and governance. (Russell and Fowler 2010)

I set out a possible conceptual and epistemic grounding for investigating civil society in Africa on its own terms. I do so in a somewhat polemical way. This is to help ensure that outcomes of necessary debate about an 'African proposition' on civil society are substantive in their own right, and not as an example of anti- and post-colonial reactionism, blaming and victim hood.

It can be argued that Africa's relative subordination in the 'global centralism' of civil society thinking and comparative research has many causes. An obvious case is the lack of local resources to undertake dedicated indigenously-inspired enquiry or to self-create a critical mass of African scholars in this field (Fowler 2002). Africa's subordinate position when compared to the institutional wherewithal of the Northern scholarly establishment results in an exogenous understanding and vocabulary of civil society. What is endogenous is either yet to be forcefully articulated or has already been subsumed within the international mainstream because it is too intellectually 'thin' or peripheral to carry much weight. This is not to reify locally-framed research or to argue that it could or should be immune from other sites of knowledge generation. But without adequate self-formulated efforts, Africa's empirical reality will remain systematically marginalised when it comes, for example, to solving the problem of determining an 'appropriate reductionism' and substance of the language, concepts and metrics required for multi-country comparative research (e.g. Anheier 2004, 2007).

That Africa has been both 'underrepresented' and its distinctive features 'underweighted' in global research on civil society is not difficult to demonstrate. In addition to the northern locus of research financing, conditional 'participation' of national researchers and the rules of the game employed in the 'ownership' of data and knowledge are additional explanations for this prejudicial outcome. One result is weighting international research towards non-African geo-histories, typologies, categories and values (e.g. Bereketeab 2009). A working premise, therefore, is that positive, remedial impact on the global state of knowledge about civil society requires a process of self-defined, endogenous research, rooted in and driven from the continent. To pursue this argument, this article unfolds in four stages, thus: a critical examination of the prevailing international discourse as it plays out on the African 'battle ground' of knowledge; a review of what might be considered specific to African conditions that co-determine its civil society 
'particularisms'; and a preliminary reflection on what the foregoing might mean for measurement.

An important caveat regarding scope and intention is in order here. Anticipated research approaches and agendas will embrace a continent of 53 countries-a quarter of the global total-exhibiting significant diversity. At best, as a heuristic device that is indicative and not prescriptive, this article puts forward a reasoned line of thinking about what endogeneity of civil society research might mean. Critique and debate will of course have to follow.

In the next section, I review the conceptual terrain that has dominated mainstream empiricism since the 're-discovery' of civil society some 20 years ago and continues to do so (e.g. Cohen and Arato 1992; Deakin 2001; Malena 2008). It is a complicated story, in part because it turns on the way that language, labels, categories and meanings are selected and used to exploit the power of defining the research universe (Moncrieffe and Eyben 2007). Vocabulary, epistemic grounding, definitions, and the boundary setting they imply, are therefore critical topics for exploring African-centred research.

The third section of the article explores what the parameters of such a research undertaking might look like in terms of empirical grounding. It adopts a geohistorical perspective with varying time frames to identify potentially differentiating features of what could be defined as 'African' civil society or, alternatively, civil society with African characteristics, that can be distinguished from civil society in Africa. This latter category would include all sorts of foreign-created, owned and financed entities typically engaged in humanitarian relief and development efforts. Analysis in terms of rootedness requires an exploration of associational life allied to the nature of statehood on the continent. Doing so brings out the issue of citizenship from which civil society draws its conceptual roots. As a background to other contributions, a short concluding section offers ideas about what to measure.

\section{A Global Lens of Civil Society: Africa as Battle Field and Playing Field}

The coming together of a global lens through which to delineate, understand, enumerate and interpret civil society is both messy and ongoing. It is a multidisciplinary battlefield of theory and a playing field for international relations, domestic public policy and development agendas both foreign-aided and otherwise. It is fraught with languages tied to concepts and categories that, in the name of pragmatism, are often carelessly treated as equivalents. Examples of anglicized, misleading equivalences are found in loose conflations between civil society organizations (CSOs), nonprofit organizations (NPOs), nongovernmental organizations (NGOs), voluntary organization (VOs); voluntary development organizations (VDOs); third sector organizations (TSOs), and more. In addition, as a political epistemology in which power stands central, the notion of civil society constituting a 'sector' is problematic in that this term relies on institutional economic theory, premised on comparative advantage (Alford and Friedland 1985). Moreover, 
'sector' is confusingly applied as a catch all term for phenomena with little or no similarity. ${ }^{1}$ For both analytic and research purposes, the concept of 'domain' allows for a less pre-determined framing of civil society. ${ }^{2}$

If 'measuring' is to be robust and honest, the constructs and labels used must have a particular ontology, researchable composition and epistemology that needs to be respected and conceptually related to each other. When added to the ill-defined categories such as a 'sector' and 'civil society' itself, laxity allows all sorts of abridging mis-conceptions and agendas to arise and seek power over discourse. Against this backdrop, it is important to find a way in which each analytic category has its place within an epistemic coherence and logic. This criterion is a challenge for what follows.

\section{Establishing Concepts and Terminology}

Civil society is a political category and construct. Its measurement requires a political framing. A logical, well-theorized and conceptually consistent way to do so is through the relationship between a nation state, citizenship and civic agency. In this progression, the world is built up from nation states as a geo-political category that represents an inter-generational 'political project' (Dagnino 2005). A polity enjoying citizenship is a legitimizing condition for a modern state (Heater 2004). It is also simultaneously an individual and collective identity which is far from uniform in what it means and how it is valued country by country (Gaventa and Jones 2002). In exerting 'agency,' each citizen acts as a co-driver and coproducer of a society's processes. Decisions about (not) applying agency simultaneously incorporate past experience, future aspirations and an assessment in the present of the effort, uncertainties and risks involved in their realization (Emirbayer and Mische 1998). In a nation state as a common political project '...civic agency is a predisposition toward, and a capability for, leading life together with others in a society and being concerned for the whole. Agency which is considered 'civic' incorporates a basic principle of an equitable, democratic society' (Fowler 2009, p. 150). Non-civic agency-corruption, market collusion and cartels, discrimination, xenophobic exclusion, denial of rights, abuse of office, intolerant fundamentalisms, vigilantism, insurgency and so on-also exist and codetermine how states evolve. In other words, the epistemic foundation of civil society is normative and has to be investigated as such. Goren Hyden voices this proposition thus:

\footnotetext{
${ }^{1}$ An example are categories used for reporting allocations of official aid to the Development Assistance Committee (DAC) of the Organisation for Economic Cooperation and Development (OECD). The label 'sector' is applied to heath care, education, investment in physical infrastructure such as roads, to nongovernmental organizations (NGOs) and support to governance.

2 A domain is understood as a social system of human activity and associated knowledges with designated (set of) attributes that are non-exclusive, that is any but not all attributes can feature in other domains. In other words, domains can overlap seen, for example, in the increasing emergence of 'hybridity' of Civic Corporations (Zadek 2001) and of third sector organisations (Billis 2010).
} 
Is civil society a community or a mere aggregate of associations? This question raises two issues of importance: the first is whether or not we like to fill the concept with a normative content, the second being what, if we take the former position, that normative content should be. It is significant that a majority of analysts and observers have treated civil society as an aggregate of organizations rather than as a community with a minimum of agreed-upon norms that define it. In short, civil society has been treated in a functionalist rather than normative manner (Pratt 2003).

The problem with these analysts is that they have implicitly assumed that civil society performs a positive role in development; more specifically, that it contributes to democratization. In this sense, these functionalists operate with a hidden normative agenda. ${ }^{3}$ We know from empirical evidence, however, that not all civil society organizations are necessarily democratic or that they contribute to a more democratic society. Many organizations, such as a good number of NGOs in Africa, are not democratically constituted, but serve the interests of a very small group of persons. (Hyden 2002)

To make sense of location and interpretation, measurement therefore needs to cope with normative features of the terrain. In addition, irrespective of livelihood, individually and collectively, citizens exert civic agency in whatever they do. Like citizenship, civic agency has no 'sector', 'arena' or specific institutional home. However, whilst the inferred rights-based substance of citizenship varies enormously across countries, an assumption that some degree of citizenship is in play underpins any angle into measurement of civil society. In this field of study, the nature of citizenship and state-society relations therefore needs analytic attention.

Agency-what people do with their lives that make up how a country functions and evolves - can be applied for an infinite number of reasons, in any number of ways at different 'sites' in a nation state. Political theory offers no consistent basis for categorizing sites for civic agency beyond, perhaps, a historically fluid, essentially contested and context-defined distinction between public and private spheres of life, often with fuzzy borders. This lack of consistency feeds the ongoing (definitional) debate about what civil society is. Such unresolved debates partly motivate and reflect objectives and methods that lie behind multi-country civil society research discussed in the next section. But before reaching this point, taking the previous factors into account, we need a framework to locate suitable categories, labels and meanings for Africa-centred research with wider perspectives and intentions.

\section{An Analytic Framework for Civil Society Research}

Drawing on the now extensive literature and debates shown in the references (Eade 2000; Howell and Pearce 2001; Heinrich 2005) and applying the analytic progression described previously, the figure below proposes a set of logically connected

\footnotetext{
3 An associated, deeper lying narrative assumption is a convergence of all states towards modernity exhibited in the developed world.
} 
categories for consideration. The world order is composed of a socio-political system of nation states where each member is located in geographies of political regions and fluid country groupings, such as the G8, G20, G77 and so on. Whilst China and Fiji may be hardly comparable, perforce the nation state is a boundary for civil society research in the first instance. The 'collective' political agency of individual citizens determines how a state functions and evolves. In this schema, civil society is but one of many domains where (non-)civic agency occurs. Sub-categories operate within civil society and there are overlaps with other domains explained later.

The domain of civil society can be understood in many political ways (e.g. Cohen and Arato 1992; Hodgkinson and Foley 2003; Edwards 2004). One is the Habermasian sense of acting as a political space for communication and interaction between citizens pursing individual and collective interests that co-determine how a society functions. Or, following Alexis de Tocqueville and John Dewey, civil society is an associational force for attaining, pluralizing and overseeing a democratic, market-driven political order. Or, following Antonio Gramsci, it can be regarded as a site of agency which resists class-based hegemonic predilection of states towards its territory and citizens. In Gramsci's view, civil society is also a 'location' for agency which counters the extractive and accumulative logic and monopolistic predispositions of capital. Research can help adjudicate if (a mix of) these or other conceptions of civil society better characterise the lived reality of Africa's citizens and their power relations.

It is important to note that in this schema (non-)civic agency is also exerted by citizens' actions, be they employed by government or profit-making businesses or making a living through informal means. Citizenship is an attribute irrespective of an individual's source of livelihood and is indifferent to the logic of these institutional distinctions. The analytic frame also recognises that there are overlaps and fuzzy borders between domains of civic agency, explored in more detail later. Major domains of the framework are described next, starting with the politics which is supposed to connect citizens to state authority.

\section{The Domain of Politics and Regimes}

The political system is an apparatus to connect citizenship to civic agency and to regimes that control the instruments of government and public administration. Almost everywhere in the world, (party) politics is problematic mechanism in terms of ensuring citizen's exert democratic control over those who exercise public authority in their name (e.g. Marquand 2004). Contending theories of civil society pre-suppose that popular control over those in authority is a preferred condition of state-society relations. This normative proposition cannot be assumed for Africa a priori. For reasons described later, there is a systemic tendency of ruling regimes on the continent to avoid the uncertainty that robust democracy would require.

The essence of democracy is political uncertainty, and it takes two distinct forms; institutional and substantive. Institutional uncertainty-the uncertainty about the rules of the game-implies the vulnerability of the democratic system to anti-democratic forces. Substantive uncertainty-the uncertainty of 
the outcomes of the game-is about the perceptions of ruling political elites in a democratic system on whether they will be returned to office. The formerinstitutional uncertainty-is bad for democracy for it raises the prospect of the return to authoritarianism in the Third Wave of democracies. The lattersubstantive uncertainty-is good for democracy for it keeps politicians on their toes, and makes them responsive to their citizenry. (Habib 2004, p. 4, after Schedler 2001, p. 19).

In Africa, attaining a robust system of governance by means of political parties is particularly problematic. The continent is the home to most of the world's fragile and failed states, with enduring conflicts and disorder that serve political ends (Chabal and Dalouz 1999; Reilly and Nordlund 2008). That this condition will impact on African civil society is a reasonable working proposition that needs to inform research (Fig. 1).

\section{The Domain of Governance}

A (supposedly) sovereign government and its public administration are meant to provide a necessary minimum of security, stability and conditions which create well-being of citizens in conformity with respect for their rights and fulfilment of their responsibilities. The extent to which a government does so is charted in a wide range of international comparative tables. For example, Human Development Indicators are but one of the 178 measures applied to countries of the world (Harris et al. 2009). For most measures of human well-being and governability, African countries can be found in the bottom quartile. This positioning points to a systemic problem of governing in the Weberian sense of inadequate procedural rationality and territorial control. It also reflects the poor quality of governmentality in Foucault's sense of public positions being used for private ends with endemic corruption an oft-cited example. An implication is that effective government at multiple levels of its functioning requires more civic rather than non-civic agency of rent-seeking, immunity and predation. Research must therefore be sensitive to the combination of power and values that operate between governors and the governed.

\section{The Domain of Civil Society: Its Constituents and Voluntarisms}

The category '(non-)civil society' is constituted by self-formed entities. They are established to pursue a shared purpose, generating a value that makes the effort worthwhile over whatever time period makes sense to those involved. Organisations of civil society exhibit 'freedom' in terms of associational life. Within what is not proscribed by law and custom, they exhibit an unlimited range of purposes. There is no a priori harmony in agency within civil society. Indeed, contention between citizens' interests is a force driving politics and a country's evolution (Fine 1992; Bratton 1994). Pro- and anti-abortion CSOs and conflicting religious groupings are examples.

Membership of one or more CSOs may be self-willed or socio-culturally prescribed. A CSO is both inclusive of those who belong and exclusive of those who 


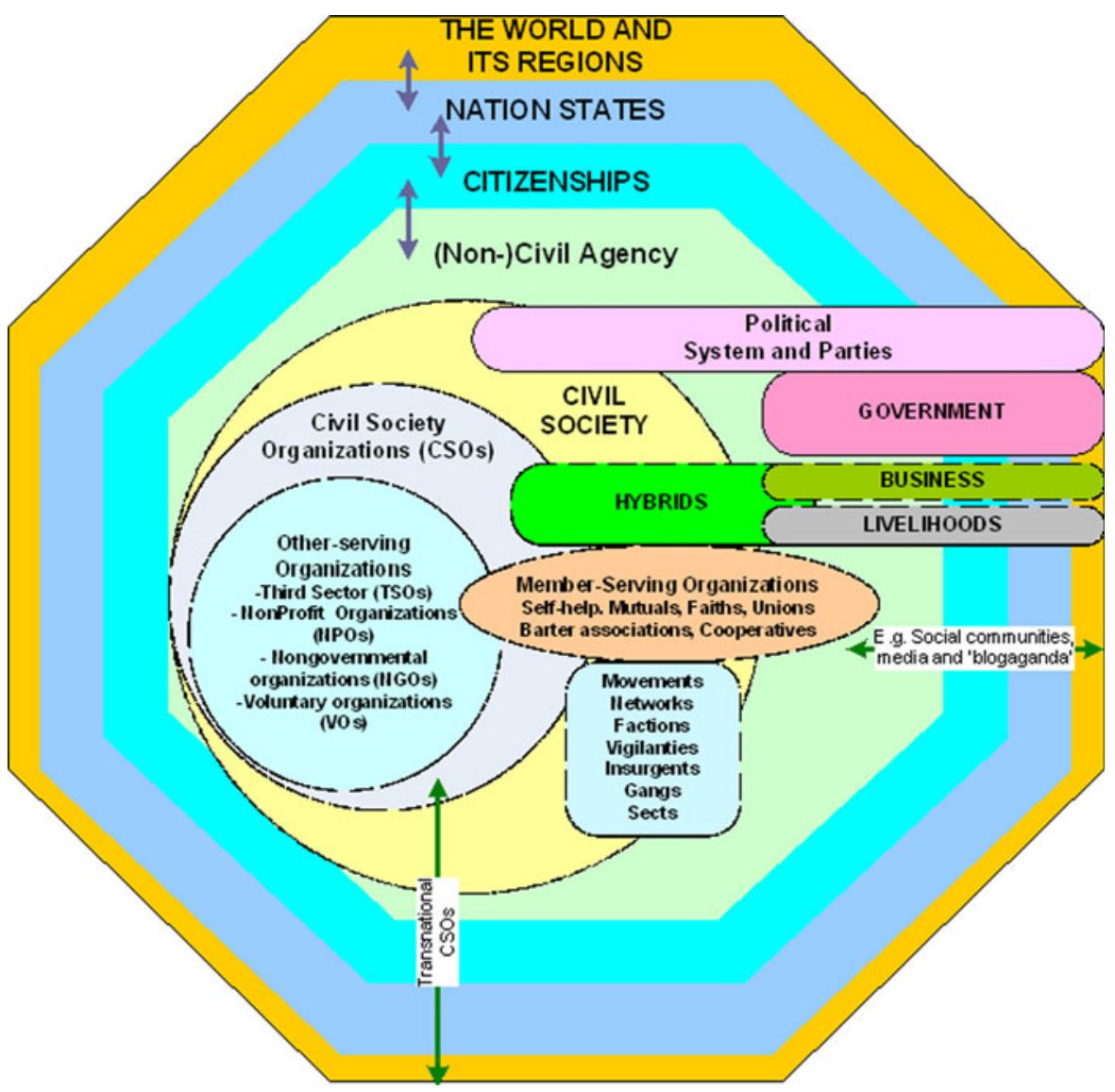

Fig. 1 Analytic framework

do not. It is a co-factor in shaping a person's identity. It also has normative (civic and non-civic) characteristics that affect relations within its domain and to other domains, particularly towards government. For example, xenophobic CSOs can cause instability that governments will seek to pre-empt and contain.

In addition, civil society is a multi-tiered, socio-political phenomenon. We can observe that its actors, their forces and processes, operate at multiple scales and durations with differences in connectivity.

A research challenge is to cope with the range of expressions of (non-)civil society in terms of their logics, use of freedoms and degrees of formalism. Doing so confronts a terminological obstacle course.

There are considerable problems with terminology, however. Although the voluntary, community and not-for-personal profit sectors are frequently taken to comprise the 'Third Sector' each of these sectors or sub-sectors have quite different characteristics. The community sector is assumed to comprise 
volunteers (unpaid) whilst the voluntary sector are considered (confusingly) to employ staff working for a social or community purpose. In addition however, the not-for-personal-profit sector is also considered to include social firms (such as cooperatives and mutuals) and more recently governmental institutions that have been spun off from government, although still operating fundamentally as public service delivery organisations. These other types of institutions may be considered to be quasi-private or quasi-public sector rather than stemming from direct community benefit motivations. ${ }^{4}$

It can be argued that this messy, complicated and confusing condition of logics with CSOs stems from the experience of modern states and economies with hundreds of years of organic growth and continual enhancement of civic agency. Rather than being encumbered by this level of refinement, it would be both prudent and more analytically robust to start from associational first principles that draw on theories of collective action and 'gifting' associated, respectively, with Olson (1971) and Mauss (1969). A simple division in this direction is between two initiating purposes of civic agency within CSOs to (1) serve other parties or (2) to serve members in a cooperative arrangement.

CSOs serving third parties contain a range of non-profit organisations (NPOs) that are often subsidised or rely on fees for services to cover costs. Non-profit hospitals run by religious organisations are an example. Confusingly, alongside rather than within the category of NPOs are NGOs. This NPO-type has a long specific historical and international attribution (Fowler 2010a). NGO has mutated into an ill-defined array of entities and a specific discourse that defy empirical clarity and legislative coherence (Tvedt 1998; Hilhorst 2003). ${ }^{5}$

To greater or lesser degrees third-party serving TSOs, may rely on voluntary labour and people's time. But because socio-cultural values often ascribe motivations for 'helping', what voluntarism means can only be locally determined (Dekker and Halman 2003). This critical point is addressed in section three.

A separate, but sometimes overlapping category with NPOs and NGOs, are CSOs established to serve members. This type of arrangement spans domains. Many are recognised and registered as entities creating economic value for those who join. However, they are often 'traditional', deeply embedded and 'invisible' to outsiders because they are simply part of the social fabric and do not need or seek formal recognition from a government authority. In fact, they may actively avoid recognition by a predatory state. Self-help women's groups, neighbourhood watch committees, traditional pooled labour arrangements, entities that manage communal natural resources are examples. They are sources and resources of social capital that civil society relies on (Wilkinson-Maposa et al. 2005).

\footnotetext{
${ }^{4}$ http://en.wikipedia.org/wiki/Voluntary_sector. Viewed on 18th February 2011.

5 National legislation induces by counter terrorism measures have, for example, increased to confusion between civil society and NGOs as well as generally constraining lawful purposes. Ethiopia and Uganda are two recent examples. For country-specific details see, International Journal of NonProfit Law and The International Journal of Civil Society Law.
} 


\section{The Domain of Civic Fluidity}

Civil society also includes self-formed fluid entities. Examples are networks and other self-organised arrangements, such as social media (Twitter, Face book) and communities of practice and professions (LinkIn). These formations are distributed across space but connected in real time. Like factions and social movements, such arrangements emerge, stabilize and disappear as ideas and issues come and go (Tilley 2004). The socio-political impact of fluid formations of civic agency can be negligible or more far-reaching (Shirky 2008). Recent mass civic upheavals and regime change in Tunisia and Egypt are examples of the latter. They illustrate a dilemma of civic agency-employing uncivil behaviour to gain civic ends. Recognition and measurement of these forms of civic self-mobilization and engagement are tricky, but necessary (e.g. iScale et al.2010). Be that as it may, it cannot be assumed, on face value, that they are less meaningful for impact on a state's evolution than 'conventional' CSOs that operate day in, day out, to stabilise or change society.

\section{Resourcing and For-Profit Connections}

Civil society requires a material/economic base for its functioning. In their "pure form' CSOs rely on the 'gift economy' of private donations in cash, kind and time. Sources can be local or from further afield. For example, in terms of civic agency that may or may not finance CSOs, in 2008, Diaspora remittances for Africa, were estimated at between 9 and 24\% of country GDPs and up to $750 \%$ of official aid. Country studies by Johns Hopkins University indicate that, for CSOs at least, private sources can be complemented and dwarfed by public financing, typically to provide public services (Salamon et al. 2004a). Increasingly, however, particularly in states with well-established welfare provision, to cope with conditions of austerity, CSOs are increasingly turning to for-profit activities as a source of income leading to the emergence of hybrid types that function on dualistic logics (Billis 2010). This type needs analytic attention and tailored measurement approach.

In somewhat of a parallel, businesses are taking up the banner of corporate social responsibility (CSR). With different degrees of commitment, firms are seeking to burnish their reputations as accountable corporate citizens (Zadek 2001; Bendell 2005) accepting a social as well as economic (and environmental) logic for that they do in and for society. Similarly, gaining livelihoods that are located in informal economies involves (non-)civic agency that can combine the social values aspect of civil society and even its organisational forms with commercial undertakings. The social capital of (women's) groups operating collectively to satisfy requirements for accessing individual loans in micro-finance are a common example of such hybrid arrangements (e.g. Hossain and Rahman 2001; Fowler and Kinyanjui 2004), which also has a non-civic shadow side (Obo 2009). Measurement needs to be sensitive to the extent to which these forms of hybrid overlap into the civil society domain. 


\section{Scale and Location}

In all of the above instances, civic agency is not limited to any particular level of socio-political organisation. Nor is it constrained to transacting across borders through official, state channels or mechanisms. Alongside governmental pathways - and increasingly through communications technology-(non-)civic agency spans the world in a sort of new 'blogasphere' and international self-assembled virtual communities which, through 'viral' effects can exert significant influence. But what is global, is always located somewhere 'local'. As such, even these civil society manifestations must be amenable to grounded research and appropriate measurement.

\section{Coherence}

The coherence of this analytic framework is argued to lie in the overarching concept of agency and its socio-political expression as citizens maintain or try and change the way society works for themselves and, implicitly, for others. This effort happens in all walks of life. Further, in order to avoid the terminological confusions of existing discourse on civil society, first principles are relied on to investigate civil society in a grounded way.

\section{The Global State of Play with Respect to Civil Society Measurement}

As a researchable concept, civil society is a 'battlefield' of narratives. It is also a global 'playing field'. Pro-civil society policies are being propagated through the discourse and channels of international relations and norms of global institutions (Scholte 2002). Promoting civil society is part and parcel of a normative, universalist, rights-driven Western agenda (Tandon 1991; Wallerstein 2006). It is important, therefore, to recognise that an Africa-centric research agenda touches on the politics of knowledge and of geo-political interests. This fact will influence how endogenous research initiatives are likely to be understood, portrayed, critiqued and supported or not.

There seem to be three major strands or lines of discourse that continue to shape civil society concepts and interpretations. Whilst there is increasing interest in 'measuring' civil society as a transnational or global phenomenon (Clark 2003; Batliwala and Brown 2006), for each strand the nation state is the geopolitical unit of most relevance for measurement. One strand of enquiry is essentially economic: what is civil society worth to a country (e.g. Salamon et al. 2004b; Salamon 2010)? Another strand is directly political: where does civil society belong in terms of the nature and distribution of power relations (e.g. Deakin 2001)? To some extent, the third strand ties the two through the lens of institutions and rules that regulate and guide a society: where does civil society belong in determining the way states evolve and are (democratically) governed and at what cost? (e.g. McGinnis 1999). Each strand has its own theory and corresponding set of metrics. Each strand also brings its own variety of perspectives and arguments as well as debates within and between them (e.g. Hann and Dunn 1996; Anheier 2005, 2007). 
The results of these narratives are three objectives of measurement involving civil society (Fowler 2011). ${ }^{6}$ The objectives can be seen as follows:

- Measuring the value of civil society to an economy-emphasis on policy reform.

- Measuring civil society in power relations between citizens and statesemphasis on political systems reform (towards democratization).

- Measuring civil society with respect to the performance of governingemphasis on institutional reform.

In each case, researchers need to cope with common problems of measurement required for comparative analysis. Three challenges are of particular importance in terms of civil society research. They are:

- Defining the observable universe to be 'measured' in all research contexts- the challenge of comparability.

- The optimal positioning of research framing, parameters and indicators between the universal and the particularistic - the challenge of reductionism.

- Avoiding any implicit or making explicit any normative bias in concepts, categories and instruments - the challenge of values/biases embedded in theory, language, concepts, etc.

All research initiatives select solutions to these challenges that suit their objectives. In this sense, existing measures need not be directly comparable. But problems arise when, in the battlefield of knowledge and ideas, one claims primacy in terms of explanation that is globally applicable.

Global research on civil society has been predominantly informed by modern perspective of western societies in general and market-driven, capitalist economies in particular. For example, two of the largest of such studies on civil society find Africa with its 53 countries (some $26 \%$ of the world total) significantly underrepresented. The CIVICUS Study includes $4(8 \%)$ countries on the content in a total of 45 researched (Heinrich 2007a). In its sample the Johns Hopkins study's 'global' coverage includes 6 African countries, $13 \%$ of the total. This article argues that the multi-country studies undertaken to date exhibit biases that mask the ontology of Africa's civil society that stems from a particular combination of forces in its historical trajectory not seen on other continents. The challenge and invitation to African scholars is therefore one of investigating civil society from within. What this might look like invites answers to the question: what is particular about (subSaharan) Africa that measuring civil society needs to be aware of? Is there an African particularism?

\section{African Particularism: An Afri-Centric Civil Society?}

Reviewing data on civil society from a limited number of African countries involved in the CIVICUS study, Paul Opuku-Mensah relies on a particular historical

\footnotetext{
${ }^{6}$ Some research programmes combine all three, e.g. Heinrich $(2007 a, b)$.
} 
trajectory that he considers sui generis $(2008, \mathrm{p}$. 76). That is, a phenomenon that is distinct to and of itself. His schema starts with the pre-colonial phase. In this era, the substance of later civil society is to be found in location-specific communal relations of solidarity (see also Wallerstein 1966; Salole 1991). A subsequent colonial phase dominated by the Treaty of Westphalia and Cold War rivalries (Adebajo 2010) saw an ethno-centric formalization of CSOs as one response to displacement by rapid urbanization and monetization of the economy, allied to the introduction of wage labour and taxation. This evolution fed into and was fed by nationalist and pan-Africanist political mobilizations for independence that introduced an additional cross-cutting, class-based character of civic agency and organisation (Muchie 2003). Rural-urban linkages started to characterise many informal associational forms and arrangements. The penetration of foreign religions also acted to both bring an additional differentiating identity to ethnicity on the one hand (e.g. Nigeria, Uganda) and to bridge ethnicity in others (e.g. Kenya, Malawi).

Though armed insurrection sometimes occurred and civil disobedience was often in play, achieving stage three, the post-colonial era, was characterised more often than not by negotiated transfer of power to urbanized and educated elites. Broadbased mass political conscientization and mobilization did not often characterise struggles for independence. The emerging dispensations became dominated by the need for new political elites to consolidate power and national identity. Typically, this occurred through processes of single party national building or military rule and autocracy. Civic agency was curtailed and civil society was co-opted or captured or repressed (Chazan et al. 1993). Civil society was a casualty of its anti-colonial activism (Hyden 2002, p. 1). Its functions were restricted to service provision as a supplement to state services. This purpose was aided by a significant influx of international NGOs. Their resources and self-replicating practices established a 'semi-detached' dependent type of African CSO. In other words, if one adds foreign entities, civil society is both of and in Africa. Indeed, the emergence of NGO-ism acted as a significant 'two-faced' feature of the socio-economic and political landscape (Ndegwa 1996), often acting as a 'holding ground' for aspiring politicians outside the single party hegemony (Bratton 1988).

The 'second liberation of Africa' (Bboya and Hyden 1987) in the late nineteen eighties heralded stage four: the start of a period of very uneven democratization relying on competitive systems of governing. This stage was, and still is, characterised by the incomplete, contested introduction of multi-party politics. These often conflictual processes offered an expansion of space for 'strengthening' civil society to take on more overt political tasks through advocacy, lobbying, involvement in constitutional reform and so on (Robinson 1995, 2000). This evolution continues in uncertain ways. For example, recent legislation in Ethiopia and Uganda re-define what is understood by civil society and constricts what is permissible in terms of its functions.

What needs to be critically borne in mind is that these stages do not replace what has gone before. Rather, they add multiple layers, connections and dimensions to civic agency and the complexity of associational life within the public arena of civil society. Specifically, these long historical processes lead to dynamic distributions of civic agency within civil society between relatively visible organisations and other 
arrangements that measurement needs to capture. But measuring also involves African factors that are more profound than this schematic introduction captures.

The distinctiveness of an African civil society perspective also lies in the politics of state formation that fosters their frailty, failure and problematic interface with citizens. Jeffrey Herbst (2001) analysed pre-colonial states and power in Africa. Whilst open to debate, (Robinson 2002) Herbst's line of argument is that low population density due to pathogens (Diamond 1999, 2004), lack of land scarcity and traditions of communal property with usufruct arrangements did not require evolution of sophisticated fiscal and similar institutional arrangements. Power relations between ruler and ruled did not need to resemble what was happening in other parts of the world, particularly the hundreds of years of Europe as a battle ground for territory. Herbst's conclusions point to why, from indigenous ways of governing, responses to external forces and penetrations have evolved to make many contemporary African states unstable, predatory, fragile, susceptible to the 'big men' syndrome and to the Politics of the Belly (Bayart 1993; Chabal and Dalouz 1999). The result is a continent characterised by states with dual publics (Ekeh 1975) and without citizens (Ayode 1988).

Arguably, the consequences of this line of reasoning can be found in the perspectives of studies on African civil society (e.g. Bayart 1986; Bratton 1988; Chazan et al. 1993; Hyden 2002; Hyden and Hailemariam 2003; Sogge 2004; Edwards 2009; Bereketeab 2009). They generally point to an associational life of citizens in a complex 'semi-disconnected' relationship with the political system that, to be properly understood, need to be investigated from below, so to speak. One reason for this phenomenon was many the years of post-colonial rule in which people 'escaped' from predatory government and the 'struggle entitlements' of new political elites. Seeking security in ethnic loyalty was a common strategy. Citizenship and allegiance to the state does not feature strongly. ${ }^{7}$ The success of this 'exit' approach for civic agency was assisted by the fact that international aid provided significant financial resources (as well as often creating unserviceable debt). For some 20 years and more, donors' Cold War driven political patronage, tied aid and humanitarian 'largesse', weakened the need for domestic taxation and popular demand for accountability that went with it (Adam and O'Connell 1997). In other words, foreign assistance worked against establishing a binding politicaleconomy between the ruler and the ruled. This legacy impacts on the nature of civic agency and the economic base of civil society. Thus, whilst the idea that civil society needs to be strengthened applies more widely, the notion that it has to be 're-built' in Africa suggests something quite specific.

It's obviously impossible to generalize across contexts as diverse as Egypt, Senegal, Somalia, Malawi and South Africa, and I claim no particular expertise in any of these contexts, but a thumbnail sketch of key issues might start by recognizing that early work on civil society in Africa-which tended to deny the applicability of the concept completely or look for patterns of associational life that replicated those familiar from the West-has been

\footnotetext{
7 See studies on Africa and citizenship at www.ids.ac.uk/drc.
} 
replaced by new approaches to creating civil society theories and practices with distinctively African flavours. Central to this effort is the need to reinterpret and recombine the relationships between associations based on primordial attachments of tribe and clan (a natural consequence of the ways in which African societies have been structured) and those based around crosscutting ties and affiliations, which have grown steadily over the last fifty years. (Edwards 2009, p. 4)

The foregoing narrative plays out in contexts of widespread, enduring poverty. This endemic condition weakens the material base from which active citizenship and civic agency is possible. Together with the risks involved in civic assertion, poverty pre-disposes towards 'formal' reliance on 'informal' but trusted and relatively reliable relations of reciprocity and of (ethnic) patronage (WilkinsonMaposa et al. 2005). Consequently, in (large) part, African civil society works on a multi-level system of relationships that generate and redistribute social as well as economic capital (e.g. Edwards et al. 2001).

Finally, there is a feature of African moral philosophy Ubuntu-'I am because you are'-that permeates social relations, civic agency and associational life in ways that seriously complicate research and measurement. It does so in a number of ways. One affect is to confuse and question both the utility and meaning of established terms such as philanthropy, altruism, generosity and the latter's supposed relationship to volunteering (Fowler and Wilkinson-Maposa 2012). Another influence is on the way public institutions are (mis-)understand as autonomous entities with 'impermeable' borders that are not sensitive to interpersonal relations and other affinities (Bayart 1993). For good and ill, African societies seldom work that way and this reality matters for how civil society is understood in relation to how African governance functions in an 'upside-down' way (Moore and Unsworth 2010).

All in all, a case can be made for an African 'exceptionalism' that should be factored into both the theory and method of measuring civil society. What this might mean is the subject of the concluding section.

\section{Implications for Measuring}

Africa is a continent, not a country. Its stories are many and must be given due weight. With this in mind, the previous sections seek to establish both a general case for and illustrations of distinctiveness about African civil society that should inform a dialogue about measurement. This final section provides an opening towards this discussion in two steps. First, to talk about what measurement is for. Second, what sort of features of civil society would measurement need to focus on.

\section{What is Measurement for?}

The introduction to this article argues that current data on Africa and its civil society is both weak and potentially mis-leading. If this is the case, Africa's 
self-understanding is mediated by others, whilst distorted information is used to inform politics, policy and practice that cannot be to the advantage of the continent and its citizens. In the first instance, therefore, the objective of research and measurement is to establish a robust, endogenous knowledge base on African civil society on its own terms. Its existence and substance can then serve many other purposes and needs.

\section{What Needs to be Measured?}

We need to bear in mind the problems of language, overlaps in domains and the logic of endogenous arguments. From here, the suggested analytic framework point to three areas of interest for endogenous research on civil society: contexts; substance; and power relations. Each is introduced briefly and will require dedicated and detailed work on methods and measurement.

\section{Context}

Endogenous study will be located in African states with specific historical trajectories. Most relevant for study will be features of each state that bears most directly on civil society, civic agency and relations between those who govern and the polity. These dimensions feature in past and ongoing study on civil society that can be reviewed for their experience and endogeneity. One example is the ongoing CIVICUS Index Stage 2 study which pays specific attention to the operating environment for civil society. ${ }^{8}$ Another well developed measure for context in terms of civil society_ARVIN_has been applied by the World Bank (2003).

\section{Substance}

Theories of civil society tend to focus on specific aspects of the concept to the relative exclusion of others. An inclusive, grounded, first order approach to measuring civil society would probably need to at least include these three factors ${ }^{9}$ :

- The material/economic base-what resources are mobilized and applied?

- The relational forms created for different purposes-how is civil society constituted and configured for what ends?

- The norms and values in play — what are the prevalence and distribution of civic and non-civic agency with civil society?

Determining what civil society 'achieves' in terms of co-determining a state's political project and evolutionary trajectory would be a second order measurement.

\footnotetext{
${ }^{8}$ http://civicus.org/csi/csi-phase-two08/csi-methodology-phase2. Viewed on 10th February 2011.

9 This triad bears similarity to the analysis provided by Michael Bratton drawing on theories associated with Marx (the material base), de Tocqueville (associational forms) and Gramsci (values that drive interests and direction of influence) (Bratton 1992).
} 


\section{Power Relations}

Exploring this feature of civil society requires a firm analytic grounding. The citizenship research project at the Institute of Development Studies in Brighton, provides one type of categorization and useful analytic framework (Gaventa 2007, p. 2).

Power 'within' often refers to gaining the sense of self-identity, confidence and awareness that is a pre-condition for action. Power 'with' refers to the synergy which can emerge through partnerships and collaboration with others, or through processes of collective action and alliance building. Power 'over' refers to the ability of the powerful to affect the actions and thought of the powerless. The power 'to' is important for the exercise of civic agency and to realise the potential of rights, citizenship or voice. ${ }^{10}$

This practical approach to power analysis can be complemented by a citizencentric perspective that draws on the work of Bourdieu (1997), Haugaard (1997) and Lukes (2005) (Fowler 2010b).

Identifying the parameters of an African civil society will be a critical addition to deepen the theory of Africa's politics.

Open Access This article is distributed under the terms of the Creative Commons Attribution Noncommercial License which permits any noncommercial use, distribution, and reproduction in any medium, provided the original author(s) and source are credited.

\section{References}

Adam, S., \& O'Connell, S. (1997). Aid, taxation and development: Analytical perspectives on aid effectiveness in sub-Saharan Africa. Policy Working Paper Series No. 1885, Washington, DC: World Bank.

Adebajo, A. (2010). The curse of Berlin: Africa after the Cold War. London: Hurst.

Alford, R., \& Friedland, R. (1985). Powers of theory: Capitalism, the state and democracy. Cambridge: Cambridge University Press.

Anheier, H. (2004). Civil society: Measurement, evaluation, policy. London: Earthscan.

Anheier, H. (2005). Measure for measure: A commentary on Heinrich and the state of civil society indicators research. Journal of Civil Society, 1(3), 241-246.

Anheier, H. (2007). Reflections on the concept and measurement of civil society. Voluntas, 18(1), 1-16. Ayode, A. (1988). States without citizens: An emerging African phenomenon. In D. Rothchild \& N. Chazan (Eds.), The precarious balance: State and society in Africa. Boulder: Lynne Rienner.

Balogun, M. (1998). The role of governance and civil society in Africa's development. Regional Development Dialogue, 19(2), 32-49.

Batliwala, S., \& Brown, D. (Eds.). (2006). Transnational civil society: An introduction. Bloomfield: Kumarian Press.

Bayart, J.-F. (1986). Civil society in Africa. In P. Chabal (Ed.), Political domination in Africa (pp. 109-125). Cambridge: Cambridge University Press.

Bayart, J.-F. (1993). The state in Africa: The politics of the belly. London: Longman.

Bboya, W., \& Hyden, G. (1987). Towards a second liberation: Africa and the world crisis. Development Dialogue, 2, 6-29.

Bendell, J. (2005). In whose name? The accountability of corporate social responsibility. Development in Practice, $15(3 \& 4), 362-374$.

${ }_{10}$ See also: http://www.powercube.net/. Viewed on 18 February 2011. 
Bereketeab, R. (2009). Conceptualizing civil society in Africa: The case of Eritrea. Journal of Civil Society, 5(1), 35-59.

Billis, D. (Ed.). (2010). Hybrid organizations and the third sector: Challenges for practice, theory and policy. London: Palgrave/Macmillan.

Bourdieu, P. (1997) Outline of a theory of practice. Cambridge: Cambridge University Press.

Bratton, M. (1988). Beyond the state: Civil society and associational life in Africa. World Politics, 41(3), 407-430.

Bratton, M. (1992). Civil society and political transitions in Africa. In N. Chazan, J. Harbeson, \& D. Rothchild (Eds.), Civil society and the state in Africa. Boulder: Lynne Rienner.

Bratton, M. (1994). Civil society and political transition in Africa. In IDR reports (Vol. 11, No. 6). Boston: Institute of Development Research.

Chabal, P., \& Dalouz, J.-P. (1999). Africa works: Disorder as political instrument. London: James Currey.

Chambers, S., \& Kymlicka, W. (Eds.). (2002). Alternative conceptions of civil society. Princeton: Princeton University Press.

Chazan, N., Harbeson, J., \& Rothchild, D. (Eds.). (1993). Civil society and the state in Africa. Boulder: Lynne Rienner.

Clark, J. (Ed.). (2003). Globalizing civil society engagement: Civil society and transnational action. London: Earthscan.

Cohen, J., \& Arato, A. (1992). Civil society and political theory. Cambridge, MA: MIT Press.

Dagnino, E. (2005). Meanings of citizenship in Latin America. Working Paper 258. Brighton: Institute of Development Studies, University of Sussex.

Deakin, N. (2001). In search of civil society. Basingstoke: Palgrave.

Dekker, P., \& Halman, L. (Eds.). (2003). The values of volunteering: cross-cultural perspectives. New York: Kluwer/Plenum.

Diamond, J. (1999). Guns, germs and steel: The fates of human societies. New York: Norton.

Diamond, J. (2004). Collapse: How societies choose to fail or succeed. New York: Viking Press.

Eade, D. (Ed.). (2000). Development, NGOs and civil society. Oxford: Oxfam.

Edwards, M. (2004). Civil society. Cambridge: Polity Press.

Edwards, M. (2009). The challenges of civil society in Africa. Dakar: Trust Africa.

Edwards, B., Foley, M., \& Diani, M. (Eds.). (2001). Beyond Tocqueville: Civil society and the social capital debate in comparative perspective. Hanover: Tufts University Press of New England.

Ekeh, P. (1975). Colonialism and the two publics in Africa: A theoretical statement. Comparative Studies in Society and History, 17(1), 91-112.

Emirbayer, M., \& Mische, A. (1998). What is agency? The American Journal of Sociology, 103(4), 962-1023. http://www.jstor.org/stable/2782934.

Fine, R. (1992). Civil society theory and the politics of transition in South Africa. Review of African Political Economy, 55, 71-83.

Fowler, A. (1998). Wither the third sector? A response to Estelle James. Voluntas, 9(3), 201-212.

Fowler, A. (2002). Civil society research funding from a global perspective: A case for redressing bias, asymmetry and bifurcation. Voluntas, 13(3), 287-300.

Fowler, A. (2009). Civic agency. In H. Anheier \& S. Toepler (Eds.), International encyclopaedia of civil society (pp. 150-155). New York: Springer.

Fowler, A. (2010a). Development NGOs. In M. Edwards (Ed.), The Oxford handbook of civil society. Oxford: Oxford University Press. forthcoming.

Fowler, A. (2010b). Civil Society Index. In R. Taylor (Ed.), Third sector research (pp. 49-60). New York: Springer.

Fowler, A. (2011). Future directions for civil society assessment. New York: Civil Society Division, United Nations Development Programme.

Fowler, A., \& Kinyanjui, K. (2004). Indigenising foreign seed on African soil: The story of K-Rep. Nairobi: Kenya Rural Enterprise Programme.

Fowler, A., \& Wilkinson-Maposa, S. (2012). Horizontal philanthropy among poor people in southern Africa: Grounded perspectives on social capital and civic association. In B. Moyo \& P. OpukuMensah (Eds.), The state of philanthropy in Africa, forthcoming.

Gaventa, J. (2007). Finding the spaces for change: A power analysis. In IDS bulletin (Vol. 37, No. 6, pp. 23-33). Brighton: Institute of Development Studies, University of Sussex. 
Gaventa, J., \& Jones, E. (2002). Concepts of citizenship: A review, Development Research Centre on citizenship, participation and accountability (DRC). Brighton: Institute of Development Studies, University of Sussex.

Habib, A. (2004). The politics of economic policy-making: Substantive uncertainty, political leverage, and human development. Johannesburg: Human Sciences Research Council, Mimeo.

Hann, C., \& Dunn, E. (Eds.). (1996). Civil society: Challenging western models. London: Routledge.

Harris, D., Moore, M., \& Schmitz, H. (2009). Country classifications for a changing world. Working Paper 326. Brighton: Institute of Development Studies, University of Sussex.

Haugaard, M. (1997). The constitution of power: A theoretical analysis of power, knowledge and structure. Manchester: Manchester University Press.

Hearn, J. (2001). The 'uses and abuses' of civil society in Africa. Journal of African Political Economy, $87,43-53$.

Heater, D. (2004). Citizenship. Manchester: Manchester University Press.

Heinrich, F. (2005). Studying civil society: Exploring the thorny issue of conceptualisation and measurement. Journal of Civil Society, 1(3), 211-228.

Heinrich, F. (Ed.). (2007a). Global survey of the state of civil society, Vol. 1: Country profiles. Bloomfield: Kumarian Press.

Heinrich, F. (Ed.). (2007b). Global survey of the state of civil society, Vol. 11: Comparative perspectives. Bloomfield: Kumarian Press.

Herbst, J. (2001). State and power in pre-colonial Africa. New York: Colombia Press.

Hilhorst, D. (2003). The real world of NGOs: Discourses, diversity and development. London: Zed Press.

Hodgkinson, V., \& Foley, M. (Eds.). (2003). The civil society reader. Hanover: Tufts/University Press of New England.

Hossain, F., \& Rahman, Z. (Eds.). (2001). Microfinance and poverty: Contemporary perspectives. Tampere: University of Tampere.

Howell, J., \& Pearce, J. (2001). Civil society and development: A critical exploration. London: Lynne Reiner.

Hyden, G. (2002). How can civil society be rebuilt in Africa. Paper prepared for the 'Langano Encounter', Langano, Ethiopia, March 18-22, Oxfam Canada, Ottawa.

Hyden, G., \& Hailemariam, M. (2003). Voluntarism and civil society: Ethiopia in comparative perspective. In Afrika spectrum (Vol. 2, pp. 23-215). Hamburg: Institut für Afrika-Kunde.

iScale, et al. (2010). Next generation network evaluation, London: iScale and Keystone Reporting. info@iscale.net.

Kumar, K. (1993). Civil society: An inquiry into the usefulness of an historical term. British Journal of Sociology, 44(3), 375-395.

Lewis, D. (2002). Civil society in African contexts: Reflection on the 'usefulness' of a concept. Development and Change, 33, 569-586.

Lukes, S. (2005). Power: A radical view (2nd ed.). Basingstoke: Palgrave.

Malena, C. (2008). Does civil society exist? In F. Heinrich \& L. Fioramonti (Eds.), Global survey of the state of civil society (Vol. 2, pp. 183-200). Bloomfield: Kumarian Press.

Mamdani, M. (1996). Citizen and subject: Contemporary Africa and the legacy of late colonialism. London: Currey.

Marquand, D. (2004). The decline of the public: The hollowing-out of citizenship. London: Polity Press.

Mauss, M. (1969). The gift: Forms and functions of exchange in archaic societies. London: Cohen and West.

McGinnis, M. (Ed.). (1999). Polycentric governance and development: Readings from the workshop in political theory and political analysis. Ann Arbour: University of Michigan Press.

Moncrieffe, J., \& Eyben, R. (2007). The power of labelling: How people are categorized and why it matters. London: Earthscan.

Moore, M., \& Unsworth, S. (2010). An upside down view of governance. Brighton: Institute of Development Studies, University of Sussex.

Muchie, M. (Ed.). (2003). The making of the African State: Pan-Africanism and the African Renaissance. London: Adonis and Abbey.

Ndegwa, S. (1996). The two faces of civil society: NGOs and politics in Africa. Hartford: Kumarian Press. Obo, D. (2009). Microfinance in Ethiopia: Elixir or poison? Maastricht: Shaker Publishing.

Olson, M. (1971). The logic of collective action: Public goods and the theory of groups. Cambridge, MA: Harvard University Press. 
Opuku-Mensah, P. (2008). The state of civil society in sub-Saharan Africa. In F. Heinrich \& L. Fioramonti (Eds.), Global survey of the state of civil society (Vol. 2, pp. 75-90). Bloomfield: Kumarian Press.

Osaghae, E. (2006). Colonialism and civil society in Africa: The perspective of Ekeh's two publics. Voluntas, 17(3), 23-246.

Pratt, B. (Ed.). (2003). Changing expectations? The concept and practice of civil society in international development. Oxford: International NGO Training and Research Centre.

Reilly, B., \& Nordlund, P. (Eds.). (2008). Political parties in conflict-prone societies: Regulation, engineering and democratic development. Tokyo: United Nations University Press.

Robinson, J. (2002). States and power in Africa, by Jeffrey I. Herbst: A review essay. Journal of Economic Literature, XL, 510-519.

Robinson, M. (1995). Strengthening civil society in Africa: The role of political aid. In IDS bulletin (Vol. 26, No. 2, pp. 74-76). Brighton: Institute of Development Studies, University of Sussex.

Robinson, M., et al. (2000). Aiding civil society? Democracy assistance and public policy in Africa. ESCOR Research Report, R6958. London: Department for International Development.

Russell, B., \& Fowler, A. (2010). Panel description: Measuring civil society in Africa, Mimeo.

Salamon, L. (2010). Putting the civil society sector on the economic map of the world. Annals of Public and Cooperative Economics, 81(2), 167-210.

Salamon, L., Sokolowski, A., et al. (2004a). Global civil society: Dimensions of the nonprofit sector (Vol. 1). Bloomfield: Kumarian Press.

Salamon, L., Sokolowski, A., et al. (2004b). Global civil society: Dimensions of the nonprofit sector (Vol. 2). Bloomfield: Kumarian Press.

Salole, G. (1991). Not seeing the wood from the trees: Searching for indigenous nongovernmental organisations in the forest of voluntary self help associations. Journal of Social Development in Africa, 6(1), 5-17.

Schedler, A. (2001). Taking uncertainty seriously: The blurred boundaries of democratic transition and consolidation. Democratization, 8,4 .

Scholte, J.-A. (2002). Civil society and democracy in global governance. Global Governance, 8 , 281-304.

Shirky, C. (2008). Here comes everybody: The power of organizing without organizations. New York: Penguin.

Sogge, D. (2004). Civil domains in African settings: Some issues. Avocado Working Paper Series 3/2004. Durban: Olive ODT.

Tandon, Y. (1991, April/June). Foreign NGOs, uses and abuses: An African perspective. Dossier, 81. Geneva: International Foundation for Development Alternatives.

Tilley, C. (2004). Social movements (1768-2004). Boulder, CO: Paradigm Publishers.

Tvedt, T. (1998). Angels of mercy or development diplomats? NGOs and foreign aid. London: James Currey.

Wallerstein, I. (1966). Voluntary associations. In J. Coleman \& C. Rosberg (Eds.), Political parties and national integration in tropical Africa (pp. 318-339). Berkeley: University of California Press.

Wallerstein, I. (2006). European universalism: The rhetoric of power. New York: New Press.

Wilkinson-Maposa, S., Fowler, A., Oliver-Evans, C., \& Mulenga, C. (2005, December). The Poor Philanthropist: How and why poor people help each other, Research Monograph. Graduate School of Business, University of Cape Town.

World Bank. (2003). Enabling environments for civic engagement in PRSP countries. In Social development notes (Vol. 82). Washington, DC: Environmentally and Socially Sustainable Development Network, The World Bank.

Zadek, S. (2001). The civil corporation: The new economy of corporate citizenship. London: Earthscan. 